\title{
Peluang dan tantangan pendidikan karakter di era digital
}

\section{Triyanto $^{1}$}

${ }^{1}$ Program Studi PPKn FKIP Universitas Sebelas Maret, Surakarta, Indonesia

\section{ABSTRAK}

Tujuan artikel ini adalah untuk membahas tentang peluang dan tantangan pendidikan karakter di era digital. Ini adalah penelitian kualitatif dengan menggunakan pendekatan naturalistik. Data dikumpulkan dengan cara survei, wawancara, observasi dan studi pustaka. Data yang diperoleh dianalisis dengan menggunakan enam tahapan dari Creswell. Pendidikan karakter di era digital memiliki berbagai tantangan dan peluang. Riset membuktikan bahwa era digital memberi peluang positif pada implementasi pendidikan karakter. Tantangan kita adalah bagaimana mengajari siswa untuk menavigasi etika di era digital. Beberapa tantangan yang harus dihadapi dalam pendidikan karakter di era digital mencakup keseimbangan, keselamatan dan keamanan, perundungan siber, sexting, hak cipta dan plagiarism. Para pembuat kebijakan pendidikan perlu berperan aktif dalam pengembangan berkelanjutan pembelajaran karakter secara digital untuk memastikan penerapan pembelajaran digital yang efektif.

\section{ABSTRACT}

The purpose of this article is to discuss the opportunities and challenges of character education in the digital age. This is a qualitative research with naturalistic approach. Data were collected by surveys, interviews, observation and literature review. The data were analyzed by six stages from Creswell. Character education in the digital age has various challenges and opportunities. Research proves that the digital age provides positive opportunities for the implementation of character education. The challenge is how to teach students to navigate ethics in the digital age. Some of the challenges are balance, safety and security, cyber bullying, sexting, copyright and plagiarism. Education policy makers need to participate in the continuous development of digital character learning to implement effective digital learning.
Sejarah Artikel

Diterima : 3 November 2020

Disetujui: 11 November 2020

Kata kunci:

Peluang, tantangan, pendidikan karakter, era digital

\section{Keywords:}

Opportunity, challenge, character education, diaital age

\section{Pendahuluan}

Era digital dicirikan dengan adanya teknologi yang dapat meningkatkan kecepatan dan besarnya perputaran pengetahuan dalam perekonomian dan masyarakat (Shepherd, 2011). Era Digital dapat dianggap sebagai perkembangan dari sebuah sistem evolusioner dimana perputaran pengetahuan tidak hanya tinggi, akan tetapi juga semakin di luar kontrol manusia sehingga membuat masa dimana hidup kita semakin sulit untuk dikelola. Implikasi sosial dari Era Digital sangat besar dan akan meningkat karena fungsi teknologi menjadi lebih berbasis pengetahuan.

Memahami era digital akan ikut membantu memastikan bahwa kita membangun hubungan social ekonomi yang berkelanjutan baik dengan teknologi maupun dengan pengetahuan canggih yang dibantu oleh teknologi. Era digital telah banyak mengubah cara hidup dan bekerja kita dengan menciptakan masyarakat berbasis pengetahuan. Seiring berjalannya waktu, era digital akan berdampak sama pada seluruh bidang kehidupan termasuk pendidikan.

Meningkatnya ketersediaan teknologi informasi dan Internet memberi tantangan pada pemahaman kita tentang bagaimana pendidikan diatur dan disampaikan, menciptakan lingkungan belajar baru dimana siswa yang terisolasi sekarang terhubung dengan guru dari seluruh dunia (Barbour \& Reeves, 2009; Peng \& Li-Wei, 2009). Pendidikan jarak jauh yang dimediasi komputer 
antara guru dan siswa melalui Internet telah menjadi cara pendidikan yang mampu mengatasi persoalan jarak geografis (Bušelić, 2017).

Tidak terbantahkan bahwa teknologi telah mengubah dunia pendidikan secara drastis. Saat ini, terdapat kekhawatiran tentang perilaku siswa di era digital, dari cyberbullying hingga pelanggaran hak cipta. Pendidikan karakter telah menjadi fokus dunia pendidikan selama ribuan tahun baik secara formal maupun informal (DeRoche \& Williams, 2001; Edmonson et al., 2009; Lickona, 2009). Pendidikan karakter sangat penting untuk tercapainya masyarakat demokratis yang mengandung beberapa cita-cita seperti menghargai sesama, menjaga keadilan dan kesetaraan, peduli terhadap kesejahteraan masyarakat, membantu sesama secara sukarela. Karakter sejak dahulu kala dianggap sebagai kata yang diakui dengan konotasi khusus. Dengan kata lain, ketika seseorang dianggap memiliki karakter yang baik seperti biasanya digunakan, orang tersebut juga memiliki beberapa kualitas lain seperti kepercayaan, integritas, bersemangat dan dapat diandalkan (Pike, 2010).

Dukungan publik tentang pentingnya pendidikan karakter telah dimulai sejak tahun 1960an (Ohler, 2011). Akan tetapi, kehadiran teknologi telah membuat metode pendidikan karakter harus mengalami perubahan secara drastis. Era digital memberi dampak besar pada perilaku siswa sehingga pendidikan karakter juga harus menyesuaikan. Era kebebasan dan penyebaran informasi yang begitu cepat membuat banyak orang khawatir terhadap masa depan karakter siswa. Sekolah mulai menerapkan pendidikan karakter di era digital secara informal berupa kesepakatan pembatasan akses internet bagi siswa dan menetapkan standar perilaku virtual untuk siswa. Akan tetapi, hal ini tidak cukup. Kita perlu membuat program kewarganegaraan digital formal yang berkaitan dengan pendidikan karakter di era digital secara mendalam, langsung, dan komprehensif. Tantangan utamanya adalah bagaimana membekali siswa untuk menghadapi perubahan yang sangat cepat. Artikel ini membahas tentang peluang dan tantangan pendidikan karakter di era digital.

\section{Metode}

\section{Desain dan partisipan}

Penelitian ini adalah penelitian kualitatif dengan menggunakan pendekatan naturalistik untuk menjelaskan dan mengkaji suatu fenomena dalam suatu konteks (Golafshani, 2003). Lokasi penelitian berada di Jawa Tengah sebagai salah satu provinsi terpadat di Indonesia. Penelitian dilaksanakan pada tahun 2019. Partisipan penelitian adalah guru-guru mata pelajaran PPKn yang tergabung dalam Asosiasi Profesi Pendidikan Pancasila dan Kewarganegaraan Indonesia (AP3KnI) Wilayah Jawa Tengah. Guru PPKn dipilih sebagai informan karena PPKn merupakan mata pelajaran yang salah tujuan utamanya adalah mendidik karakter warga negara (Bleazby, 2020; Sulianti et al., 2019). Pendidikan karakter di era digital adalah bagian dari diskurus kewarganegaraan digital (Hintz et al., 2017; Isman \& Canan Gungoren, 2014). Terdapat 50 partisipan guru yang terlibat dalam penelitian ini. Kecukupan partisipan pada penelitian kualitatif tidak berpedoman pada jumlah tertentu tetapi pada terjadinya kejenuhan data. Jika telah terjadi kejenuhan data maka pengumpulan data dapat diakhiri (Faulkner \& Trotter, 2017).

\section{Pengumpulan data}

Data dikumpulkan dengan cara survei, wawancara, observasi dan studi pustaka. Wawancara dilakukan secara terstruktur dengan pedoman wawancara yang telah disiapkan sebelumnya (Creswell, 2012). Pedoman wawancara berisi pertanyaan-pertanyaan untuk menggali informasi tentang tantangan-tangan yang dihadapi guru dalam mendidik karakter di era digital misalnya: (1) Bagaimana pendapat anda tentang era digital saat ini?; (2) Tantangan apa saja yang anda hadapi dalam mendidik karakter di era digital?; (3) Bagaimana upaya anda mengatasi tantangan dalam 
mendidik karakter di era digital? Observasi dilakukan terhadap interaksi guru dengan siswa baik di kelas maupun di luar kelas. Studi pustaka dilakukan dengan membaca dan menelaah buku dan jurnal tentang pendidikan karakter berbentuk cetak maupun elektronik.

\section{Analisis}

Penelitian ini menggunakan analisis data berupa enam tahapan dari Creswell (2012) yang terdiri dari: (1) menyiapkan dan mengorganisasikan data, (2) mengeksplorasi dan menyortir data, (3) pengodean data untuk membangun tema, (4) analisis deskriptif, (5) analisis lanjut dan interpretasi data, dan (6) validasi terhadap keakuratan data (Gambar 1).

Gambar 1

Tahapan analisis data

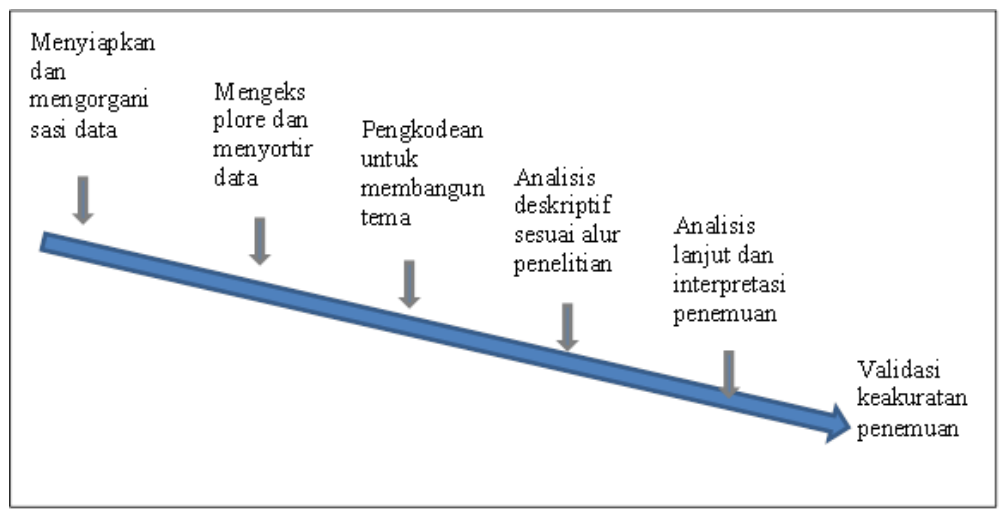

Sumber: Cresswel, 2012.

\section{Hasil dan Pembahasan}

Era digital dihadapi oleh guru dengan berbagai respons. Tidak banyak guru PPKn yang siap beradaptasi dengan pendidikan di era digital. Para guru menyadari sepenuhnya bahwa era digital merupakan sesuatu yang tidak dapat dihindari. Oleh karena itu, mau tidak mau guru harus menyesuaikan kedatangan era digital dengan mengadopsi pembelajaran digital. Pendidikan karakter di era digital juga harus mengadopsi pembelajaran digital (Pachler, 2013). Ketidaksiapan guru dalam menghadapi era digital dipengaruhi oleh dua faktor yaitu (1) faktor kompetensi; (2) faktor infrastruktur.

Kompetensi guru PPKn pada pembelajaran digital masih perlu terus ditingkatkan. Lemahnya kompetensi digital umumnya terjadi pada guru yang sudah berumur 50 tahun ke atas. Mereka tidak terlatih sejak awal menjadi guru sehingga perlu usaha keras untuk mengadopsi digital learning. Hal ini disebabkan karena mereka tidak familiar dengan peralatan digital. Guru yang berumur 40an tahun masih lebih mudah menyesuaikan dengan perkembangan digital learning karena mereka relatif sudah familiar dengan peralatan digital sejak awal menjadi guru. Guru yang berumur 30an tahun dapat dengan mudah dan lancar dalam menyelenggarakan pembelajaran digital.

\section{Peluang}

Abad ke-21 membutuhkan sistem pendidikan yang mempromosikan keterampilan dan kompetensi untuk masa depan, tidak terkecuali kreativitas, pemikiran kritis, kolaborasi dan komunikasi. Teknologi digital menawarkan peluang yang belum pernah ada sebelumnya untuk melengkapi, memperkaya, dan mengubah pendidikan guna memenuhi tantangan baru ini. Selain itu, teknologi informasi dan komunikasi (TIK) adalah alat utama untuk memfasilitasi akses pendidikan yang adil dan inklusif, menjembatani perbedaan pembelajaran, membuka perspektif 
baru bagi guru dan profesinya, meningkatkan kualitas dan makna pembelajaran, serta meningkatkan administrasi pendidikan. dan pemerintahan.

Pembelajaran karakter secara digital sangat membantu siswa mencapai kompetensi yang telah ditetapkan. Akan tetapi, masih terdapat kesalahan pemahaman guru terhadap pembelajaran digital. Pembelajaran karakter secara digital sering hanya diterjemahkan sebagai pembelajaran dengan penggunaan alat digital. Hal ini ada simplifikasi dan kegagalan dalam memahami sebuah konsep. Pembelajaran digital adalah upaya untuk meningkatkan kualitas pembelajaran dan tidak hanya sekadar pemanfaatan alat digital di kelas. Oleh karena itu, pembelajaran digital tidak dapat sebagai tren untuk menggunakan alat-alat digital melainkan suatu tanggung jawab untuk meningkatkan kualitas pembelajaran. Penelitian Davis (2020) menunjukkan bahwa pemberian akses internet saja kepada siswa tidak selalu memberikan hasil yang baik. Diperlukan integrasi teknologi yang tepat untuk memungkinkan siswa terlibat secara aktif dengan ide-ide sehingga mereka benar-benar memiliki pengalaman belajar yang berkualitas. Ini adalah tantangan nyata yang harus dihadapi guru dalam pendidikan karakter.

Konsep pembelajaran karakter secara digital cukup kompleks karena terlalu banyak variabel yang mempengaruhi. Singkatnya, Pembelajaran karakter secara digital dapat meningkatkan pengalaman belajar, menghemat waktu guru, memungkinkan guru menyesuaikan pembelajaran dengan kebutuhan siswa dengan lebih baik, membantu melacak kemajuan siswa, memberikan transparansi dalam proses pembelajaran bagi semua pemangku kepentingan, dan banyak lagi. Di antara banyak manfaat pembelajaran digital ini, sebagian besar guru setuju bahwa pembelajaran digital berdampak positif terhadap pertumbuhan dan pencapaian siswa (Gambar 2).

Gambar 2

Dampak Positif Pembelajaran Digital Bagi Siswa

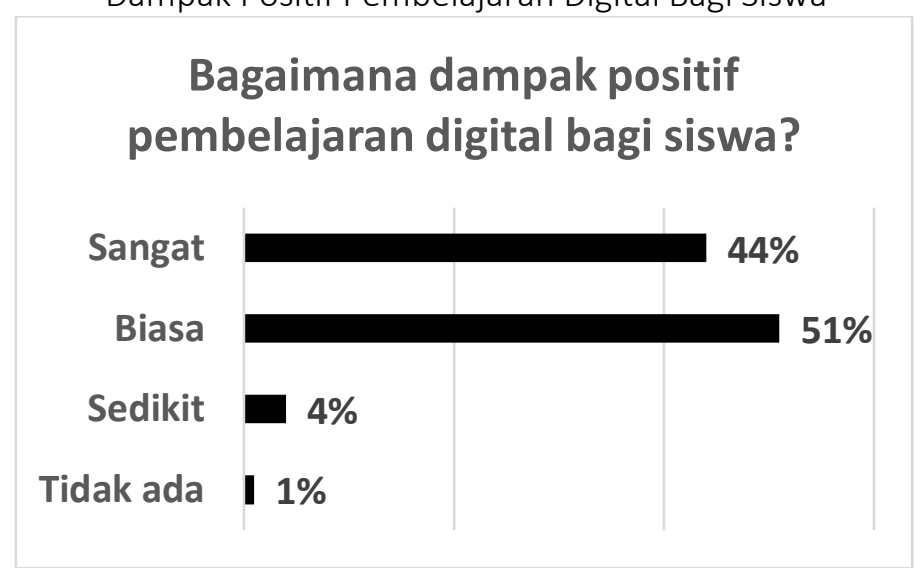

Sumber: Data Hasil Penelirian, 2020

Dampak teknologi pada pendidikan karakter sangat positif karena teknologi memberi lebih banyak kekuatan kepada orang-orang, dan memberdayakan orang untuk memecahkan masalah dengan lebih efisien dan menjalani kehidupan yang lebih baik. Pendidikan karakter bukan hanya tentang belajar menjadi aman atau mengelola risiko; ini tentang memaksimalkan prospek positif bagi individu dan masyarakat, tentang nilai-nilai kehidupan yang mengangkat orang dan kondisi manusia bahkan dalam keadaan yang paling sulit sekalipun (Jolls, 2008).

Pembelajaran digital memberi peluang besar terhadap keberhasilan dalam pendidikan karakter. Terdapat beberapa peluang dalam pembelajaran digital dibanding dengan pembelajaran tradisional.

Pertama, pembelajaran digital dapat mengurangi banyak kendala geografis yang luas. Siswa sekarang dapat mengakses video online yang memberikan instruksi tentang berbagai topik di 
berbagai tingkat keahlian, dan berpartisipasi dalam konferensi video dengan guru yang berada pada tempat yang berbeda.

Kedua, keberadaan teknologi layar sentuh telah memungkinkan anak-anak yang sangat muda untuk terlibat dalam pengajaran dengan bantuan teknologi. Sebelum adanya tablet, sulit bagi siswa prasekolah, taman kanak-kanak, dan bahkan siswa kelas awal SD untuk belajar dengan perangkat lunak pendidikan karena perlu menggunakan mouse atau keyboard. Sekarang ada ratusan aplikasi yang dapat secara efektif mengekspos anak-anak pada keterampilan literasi dan numerasi dini.

Ketiga, kemajuan teknologi kecerdasan buatan (artificial intelligence) sekarang memungkinkan guru untuk membedakan cara pengajaran, memberikan dukungan ekstra dan materi yang sesuai dengan perkembangan kepada siswa yang pengetahuan dan keterampilannya jauh di bawah atau di atas norma tingkat kelas. Sistem bimbingan belajar "cerdas" terbaru tidak hanya mampu menilai kelemahan siswa saat ini, tetapi juga mendiagnosis mengapa siswa membuat kesalahan tertentu. Teknologi ini dapat memungkinkan guru untuk lebih menjangkau siswa yang jauh dari rata-rata dalam kelas mereka, berpotensi menguntungkan siswa dengan kemampuan akademis yang lebih lemah.

Pembelajaran karakter secara digital mendorong dan mempromosikan pengembangan keterampilan penting abad ke-21 bagi siswa seperti keterampilan komunikasi dan kolaborasi serta meningkatkan prestasi dan motivasi siswa (Beldarrain, 2006; Bušelić, 2017; Smith et al., 2005). Hasil penelitian menunjukkan bahwa sekitar dua pertiga siswa yang berpartisipasi menunjukkan bahwa komunikasi dengan siswa lain merupakan bagian penting dari pembelajaran mereka dalam program pembelajaran digital (Smith et al., 2005). Selain itu, sebuah laporan penelitian mengungkapkan bahwa siswa yang bekerja dalam pengaturan online lebih termotivasi daripada mereka yang bekerja dalam pengaturan ruang kelas tradisional (Murphy \& Rodríguez Manzanares, 2008).

\section{Tantangan}

Inovasi teknologi bergerak sangat cepat sehingga kita sering kali tidak punya waktu untuk mempertimbangkan konsekuensi yang tidak diinginkan. Akibatnya, sulit untuk menanggapi masalah terkait karakter seperti cyberbullying dan sexting karena tampaknya muncul begitu saja. Tantangan kita adalah menemukan cara untuk mengajari siswa bagaimana menavigasi etika dari era digital yang bergerak cepat, secara sadar, proaktif dan reflektif. Beberapa tantangan yang harus dihadapi dalam pendidikan karakter di era digital mencakup keseimbangan, keselamatan dan keamanan, perundungan siber, sexting, hak cipta dan plagiarisme (Gambar 3).

\section{Gambar 3}

Tantangan pendidikan karakter di era digital

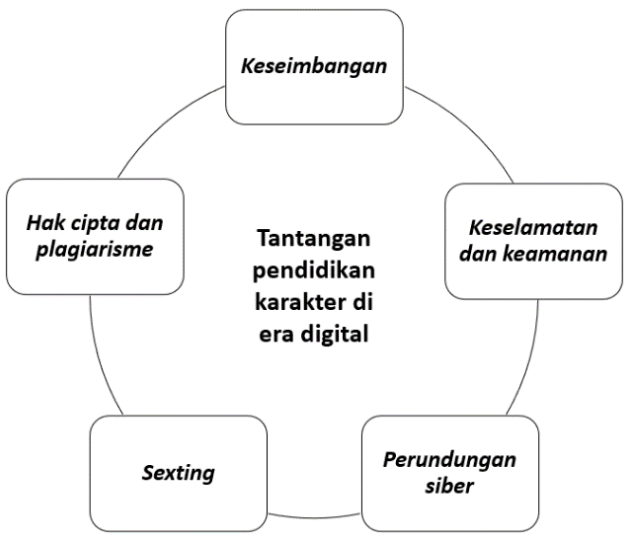

Sumber: Hasil Penelitian, 2020 
Aspek keseimbangan mengharuskan guru untuk memahami efek masa lalu, sekarang, dan kemungkinan masa depan dari suatu teknologi. Diperlukan adanya rasa keseimbangan antara peluang dan tanggung jawab, pemberdayaan dan kehati-hatian, pemenuhan kepentingan pribadi dan komunitas dan kesejahteraan global. Banyak orang mengembangkan perilaku yang mencerminkan penggunaan teknologi yang berlebihan (Charlton \& Danforth, 2007). Penggunaan teknologi yang tidak diatur dapat mempengaruhi dan mengondisikan hubungan dan interaksi pribadi, terutama orang-orang muda yang perlu merasa terhubung secara permanen ke Internet (Cuesta Cambra \& Gaspar Herrero, 2014) atau takut terputus dari teman sebayanya (Przybylski et al., 2013).

Aspek keselamatan dan keamanan mengharuskan guru untuk menyadari sepenuhnya bahwa tindakan online dapat membahayakan diri sendiri atau orang lain. Persoalan keselamatan dan keamanan mencakup perlindungan privasi diri, penghormatan privasi orang lain, deteksi terhadap situs online yang tidak pantas (seperti materi seksual dan sumber daya lain yang tidak diperuntukkan bagi anak). Keamanan online menjadi tantangan yang dapat menentukan stabilitas dan kelancaran sistem itu sendiri. Meskipun tingkat kepekaan dan perhatian yang lebih besar terhadap penggunaan internet semakin meningkat, kurangnya pengetahuan, informasi, dan perhatian dari pihak pengguna membuat mereka rentan terhadap risiko mulai dari kehilangan data hingga pencurian identitas digital. Program pelatihan diperlukan untuk membalikkan situasi ini dan mempromosikan kebiasaan baik terkait penggunaan teknologi dan jaringan.

Aspek perundungan siber (cyberbullying) mengharuskan guru untuk memahami dampak yang berpotensi merusak dari penindasan maya dan bagaimana hal itu melanggar prinsip-prinsip etika integritas pribadi, kasih sayang, dan perilaku yang bertanggung jawab. Cyberbullying baik di dalam maupun di luar sekolah, melalui teknologi, memungkinkan privasi anak atau remaja yang di-bully terus-menerus diserang. Baik penerima maupun pelaku adalah korban berbagai bentuk intimidasi online (termasuk cyberbullying, sexting, trolling, dan happy slapping) yang mengganggu perkembangan psikologis dan pribadi mereka (Patchin \& Hinduja, 2006). Persoalan sexting mengharuskan guru untuk memahami konsekuensi negatif menggunakan ponsel untuk mengambil dan mengirimkan gambar yang bersifat seksual dari diri sendiri atau orang lain.

Aspek hak cipta dan plagiarisme mengharuskan guru untuk mengajarkan penghormatan terhadap hak kekayaan intelektual orang lain dan merefleksikan legalitas dan etika penggunaan materi online tanpa izin. Menggunakan ide, kata-kata, dan karya orang lain seolah-olah itu milik sendiri disebut sebagai plagiarisme. Namun, plagiarisme tidak selalu disengaja atau berbahaya. Terkadang hal itu dilakukan tanpa disadari dan disebabkan oleh kurangnya pengetahuan sebelumnya. Agud (2014) menyatakan bahwa beberapa mahasiswa mengaku melakukan plagiarisme dan bentuk kecurangan akademik lainnya dan memperingatkan terhadap malpractice tersebut karena dapat menjadi awal dari praktik curang selama karier profesional mereka. Lonjakan teknologi digital telah memungkinkan akses ke penyimpanan, perekaman, reproduksi, dan penyebaran konten dalam skala besar, sehingga sulit untuk melindungi hak cipta dan eksploitasi komersial karya dan produksi digital (Olcott et al., 2015).

Siswa perlu diajari menggunakan teknologi dan internet secara efektif, kreatif, dan bijak. Mereka akan belajar tidak hanya bagaimana menggunakannya, tetapi juga kapan dan mengapa, dengan rasa aman, komunitas, keadilan, dan tanggung jawab. Siswa akan belajar menggunakan teknologi dan internet dengan aman dan bertanggung jawab. Sekolah harus menyediakan lingkungan yang aman, yang mempromosikan rasa saling menghormati dan memotivasi siswa untuk belajar dan bertindak secara bertanggung jawab dalam komunitas lokal dan online mereka. Pendidikan adalah tanggung jawab bersama dari rumah, sekolah, dan komunitas siswa. 
Pentingnya pembelajaran karakter secara digital sebagai solusi menghadapi tantangan pendidikan dan meningkatnya jumlah siswa yang belajar secara online, telah meningkatkan kebutuhan untuk mempelajari lebih dekat faktor-faktor yang mempengaruhi pembelajaran karakter siswa dalam pendidikan digital (Cavanaugh et al., 2004). Pada tahap ini ada banyak perdebatan mengenai apakah pembelajaran digital memberikan pembelajaran siswa yang lebih baik daripada pendidikan tradisional (Beldarrain, 2006; Journell, 2010; Nguyen, 2015). Perlu untuk memberikan bukti tentang apakah manfaat pembelajaran karakter secara digital lebih besar daripada kekurangannya, dan apakah pembelajaran digital kemungkinan akan memberikan kontribusi yang berharga bagi pendidikan karakter siswa.

Di sisi lain, banyak peneliti, cendekiawan, dan pembuat kebijakan pendidikan menentang pendidikan digital karena dapat berdampak negatif pada pembelajaran, prestasi, sosialisasi dan motivasi siswa (Barbour \& Reeves, 2009; Nguyen, 2015; Savery, 2005). Sosialisasi merupakan masalah serius yang berkaitan dengan pembelajaran digital karena dalam pendidikan konvensional terdapat harapan bahwa siswa akan belajar bagaimana berkolaborasi dengan orang lain dan menginternalisasi norma dan nilai yang diperlukan untuk hidup dalam masyarakat yang beradab (Peng, 2009). Pembelajaran digital dianggap kurang dalam pengajaran norma dan nilai komunitas dan karenanya, lingkungan belajar virtual kurang mampu menyosialisasikan nilai yang diharapkan dimiliki siswa dibandingkan pembelajaran konvensional (Beldarrain, 2006; Davis, 2020).

Di sekolah konvensional, prinsip-prinsip seperti kejujuran, menghormati diri sendiri dan orang lain, tanggung jawab dan kewarganegaraan biasanya diperkuat dengan hubungan tatap muka antara siswa dan guru, dan antara siswa (Barbour \& Reeves, 2009). Seperti yang dikemukakan Nguyen (2015), peluang sosialisasi dalam pembelajaran digital berkurang karena lebih sedikit teman sebaya dan lebih sedikit kontak tatap muka dengan orang lain. Selain itu, budaya web dianggap mengisolasi dan oleh karena itu dengan mendorong siswa untuk mengejar pendidikan jarak jauh menyebabkan hilangnya komunitas, keterlibatan sipil dan keterhubungan sosial (Barbour \& Reeves, 2009; Journell, 2010). Selain itu, dalam pembelajaran digital dimana teknologi asinkron seperti email digunakan, guru tidak dapat mengamati tanggapan afektif siswa karena isyarat seperti ekspresi wajah dan bahasa tubuh tidak ada (Barbour \& Reeves, 2009).

Selanjutnya, interaksi siswa di dalam kelas tradisional mendorong perkembangan kemampuan berpikir kritis, pemecahan masalah, dan kolaborasi (Peng \& Li-Wei, 2009). Sementara banyak program pembelajaran digital telah mengembangkan forum online atau ruang obrolan bagi siswa untuk berkomunikasi dan berbagi ide, itu hanya sebagian pengganti dari interaksi yang disediakan di kelas dengan guru dan siswa lain (Bušelić, 2017). Interaksi kelas online tidak sama, dalam banyak hal penting, seperti yang ada di kelas tradisional, dan beberapa siswa berjuang dalam lingkungan pembelajaran virtual karena keakraban interaksi siswa-guru dan siswa-siswa berkurang dan banyak mode komunikasi hilang (Murphy \& Rodríguez Manzanares, 2008).

Siswa dalam pembelajaran karakter secara digital mungkin tidak memiliki kesempatan yang lebih besar untuk berempati dengan orang lain dibandingkan dengan rekan-rekan mereka dalam pendidikan tradisional (Barbour \& Reeves, 2009). Seperti yang ditunjukkan oleh beberapa peneliti, tidak semua siswa cocok dengan pembelajaran digital dan menjadi jelas bahwa ada siswa yang tidak akan berkembang dan berhasil dalam pembelajaran digital mungkin karena pembelajaran digital menuntut kemandirian dan tanggung jawab siswa yang lebih besar daripada kursus tradisional (Journell, 2010; Savery, 2005). Selain itu, siswa yang mendaftar dalam pembelajaran digital harus memiliki motivasi diri untuk belajar (Davis, 2020). Namun, tidak semua siswa memiliki motivasi diri yang cukup untuk menyelesaikan program pembelajaran digital, mereka terbiasa di lingkungan kelas dan berinteraksi secara nyata dengan guru untuk berkembang dan mempelajari 
konten kursus (Nguyen, 2015). Selain itu, disiplin diri diperlukan agar siswa dapat menyelesaikan pembelajaran digital. Siswa yang tidak dapat mengatur waktu mereka dengan baik biasanya tidak terlalu berhasil dengan pembelajaran digital (Bušelić, 2017).

Kondisi infrastruktur internet yang baik menjadi syarat suksesnya pembelajaran karakter secara digital. Dari sisi peralatan, umumnya guru sudah memiliki peralatan yang memadai untuk pembelajaran digital. Namun demikian terdapat kendala jaringan internet yang tidak memadai pada setiap wilayah. Pembelajaran karakter secara digital memerlukan jaringan internet yang baik. Oleh karena itu bagi guru-guru yang tinggal di daerah pinggiran tidak dapat menyelenggarakan pembelajaran digital secara optimal.

Tantangan lain adalah siswa berasal dari latar belakang yang sangat berbeda dan memiliki sumber daya, peluang, dan dukungan yang sangat berbeda di luar sekolah. Beberapa siswa akan dapat mengikuti pembelajaran digital dengan baik, sebaliknya, siswa lain tidak akan memiliki akses ke apa pun yang berkualitas. Secara umum, mereka yang paling sulit secara ekonomi dalam masyarakat kita akan menjadi yang paling kesulitan dalam mengikuti pembelajaran digital.

\section{Simpulan}

Pendidikan karakter di era digital memiliki berbagai tantangan dan peluang. Riset membuktikan bahwa era digital memberi peluang positif pada implementasi pendidikan karakter. Pendidikan karakter bukan slogan atau kursus melainkan sebuah misi yang tertanam dalam kehidupan sekolah sehari-hari. Promosi pendidikan karakter hendaknya tidak hanya sekadar lompatan layanan tetapi memiliki rencana aksi untuk praktik. Secara bersama-sama, orang tua, guru, dan pengurus sebagai pemangku kepentingan, harus mendorong siswa mewujudkan nilainilai baik tersebut dalam kehidupan mereka. Pembelajaran karakter secara digital lebih dari sekadar tren. Tantangannya adalah bagaimana memberi kesempatan belajar berkualitas tinggi kepada semua siswa untuk meningkatkan cara siswa belajar dan apa yang mereka pelajari tanpa dipengaruhi oleh latar belakang, geografi, atau kondisi ekonomi mereka. Para pembuat kebijakan pendidikan perlu berperan aktif dalam pengembangan berkelanjutan pembelajaran karakter secara digital untuk memastikan penerapan pembelajaran digital yang efektif. Negara-negara dengan strategi pembelajaran digital yang kuat akan bergerak maju untuk membantu siswa mencapai potensi penuh siswa di era digital.

\section{Ucapan Terima Kasih}

Penulis mengucapkan terima kasih kepada guru-guru PPKn di Jawa Tengah yang tergabung dalam Asosiasi Profesi Pendidikan Pancasila dan Kewarganegaraan Indonesia (AP3Knl) wilayah Jawa Tengah atas kesediaannya menjadi informan pada penelitian ini.

\section{Referensi}

Agud, J. L. (2014). Fraud and plagiarisim in school and career. Revista Clínica Española (English Edition), 214(7), 410-414. https://doi.org/10.1016/j.rceng.2014.03.002

Barbour, M. K., \& Reeves, T. C. (2009). The reality of virtual schools: A review of the literature. Computers and Education, 52(2), 402-416. https://doi.org/10.1016/j.compedu.2008.09.009

Beldarrain, Y. (2006). Distance education trends: Integrating new technologies to foster student interaction and collaboration. Distance Education, 27(2), 139-153. https://doi.org/10.1080/01587910600789498

Bleazby, J. (2020). Fostering moral understanding, moral inquiry \& moral habits through philosophy in schools: a Deweyian analysis of Australia's Ethical Understanding curriculum.
Journal
of
Curriculum
Studies,
52(1),
84-100. 
https://doi.org/10.1080/00220272.2019.1650116

Bušelić, M. (2017). Distance learning - concepts and contributions. Oeconomica Jadertina, 2(1), 23-34. https://doi.org/10.15291/oec.209

Cavanaugh, C., Gillan, K. J., Kromrey, J., Hess, M., \& Blomeyer, R. (2004). The effects of distance education on K-12 student outcomes: A meta-analysis. Learning Point Associates.

Charlton, J. P., \& Danforth, I. D. W. (2007). Distinguishing addiction and high engagement in the context of online game playing. Computers in Human Behavior, 23(3), 1531-1548. https://doi.org/10.1016/j.chb.2005.07.002

Creswell, J. W. (2012). Educational research: Planning, conducting, and evaluating quantitative and qualitative research. Pearson.

Cuesta Cambra, U., \& Gaspar Herrero, S. (2014). Análisis motivacional del uso del smartphone entre jóvenes: Una investigación cualitativa. Historia y Comunicación Social, 18(Nov), 435447. https://doi.org/10.5209/rev_HICS.2013.v18.44252

Davis, L. (2020). Digital learning: What to know in 2020. www.schoology.com.

DeRoche, E. F., \& Williams, M. M. (2001). Educating hearts and minds: A comprehensive character education framework. SAGE Publication, Inc.

Edmonson, S., Tatman, R., \& Slate, J. (2009). Character education: An historical overview. International Journal of Educational Leadership Preparation, 4(1).

Faulkner, S. L., \& Trotter, S. P. (2017). Data saturation. In The international encyclopedia of communication research (hal. 1-2). Wiley. https://doi.org/10.1002/9781118901731.iecrm0060

Golafshani, N. (2003). Understanding Reliability and Validity in Qualitative Research. The Qualitative Report, 8(4), 597-606.

Hintz, A., Dencik, L., \& Wahl-Jorgensen, K. (2017). Digital citizenship and surveillance society: Introduction. International Journal of Communication, 11, 731-739.

Isman, A., \& Canan Gungoren, O. (2014). Digital citizenship. Turkish Online Journal of Educational Technology, 13(1), 73-77. https://doi.org/10.4324/9781315622408-9

Jolls, T. (2008). The impact of technology on character education. U.S. Department of Education Character Education Symposium 2008.

Journell, W. (2010). Perceptions of e-learning in secondary education: A viable alternative to classroom instruction or a way to bypass engaged learning? Educational Media International, 47(1), 69-81. https://doi.org/10.1080/09523981003654985

Lickona, T. (2009). Educating for character: How our schools can teach respect and responsibility. Bantam Books.

Murphy, E., \& Rodríguez Manzanares, M. A. (2008). Instant messaging in a context of virtual schooling: Balancing the affordances and challenges. Educational Media International, 45(1), 47-58. https://doi.org/10.1080/09523980701847180

Nguyen, T. (2015). The Effectiveness of Online Learning: Beyond No Significant Difference and Future Horizons. MERLOT Journal of Online Learning and Teaching, 11(2), 309-319.

Ohler, J. (2011). Character Education for the Digital Age. Teaching Screenagers, 68-5.

Olcott, D., Carrera Farran, X., Gallardo Echenique, E. E., \& González Martínez, J. (2015). Ética y 
Educación en la era digital: Perspectivas globales y estrategias para la transformación local en Cataluña. RUSC Universities and Knowledge Society Journal, 12(2), 59-72. https://doi.org/10.7238/rusc.v12i2.2455

Pachler, N. (2013). Perspectives on and theories of learning with digital technologies. In M. Leask \& N. Pachler (Ed.), Learing to Teach Using ICT in the Secondary School: A Companion to School Experience. Routledge. https://doi.org/10.4324/9780203124208

Patchin, J. W., \& Hinduja, S. (2006). Bullies move beyond the schoolyard. Youth Violence and Juvenile Justice, 4(2), 148-169. https://doi.org/10.1177/1541204006286288

Peng, L.-W., \& Li-Wei. (2009). Digital science games' impact on sixth and eighth graders' perceptions of science. Ohio University.

Pike, M. A. (2010). Christianity and character education: faith in core values? Journal of Beliefs \& Values, 31(3), 311-321. https://doi.org/10.1080/13617672.2010.521008

Przybylski, A. K., Murayama, K., DeHaan, C. R., \& Gladwell, V. (2013). Motivational, emotional, and behavioral correlates of fear of missing out. Computers in Human Behavior, 29(4), 18411848. https://doi.org/10.1016/j.chb.2013.02.014

Savery, J. R. (2005). BE VOCAL: Characteristics of successful online instructors. Journal of Interactive Online Learning, 4(2), 141-152.

Shepherd, J. (2011). What is the digital era? In Social and economic transformation in the digital era (hal. 1-18). IGI Global. https://doi.org/10.4018/978-1-59140-158-2.ch001

Smith, R., Clark, T., \& Blomeyer, R. L. (2005). A synthesis of new research on k-12 online learning. Research Studies, November.

Sulianti, A., Safitri, R. M., \& Gunawan, Y. (2019). Implementasi pendidikan kewarganegaraan berbasis kearifan lokal dalam membangun karakter generasi muda bangsa. Integralistik, 30(2), 100-106. https://doi.org/10.15294/integralistik.v30i2.20871 